\title{
Community-Based Education as A Form of Education Fulfilment for Children in Conflict with the Law (Abh)
}

\author{
Basuni $^{1}$, Rineka Sara ${ }^{2}$ \\ University Borobudor ${ }^{1,2}$ \\ \{basuniunboro@gmail.com ${ }^{1}$,rineke_sara@borobudur.ac.id ${ }^{2}$ \}
}

\begin{abstract}
Education is an important element that is part of the development and growth of children. For children facing the law or children who are assisted members of the Special Development Institution for Children (LPKA), education is a problem that needs to be fought for. During their sentence, many children lose their various rights, such as the right to freedom, the right to grow and develop, and the right to get an education. In general, the condition of juvenile prisons in Indonesia has not fully received a guidance program that is oriented towards fulfilling children's rights to obtain an education. There are difficulties as well as risks that arise when children facing the law (ABH) study outside LPKA. This study offers community-based education as a form of fulfilling education for $\mathrm{ABH}$. By using the descriptive-analytical method, the research presents an overview of the educational phenomenon which is closely related to the existing reality. The results of this study describe the form and application of community-based education for $\mathrm{ABH}$.
\end{abstract}

Keywords: Education; Children in Conflict with the Law

\section{Introduction}

\subsection{Educational Problems experienced by ABH}

The phenomenon of children dealing with the law $(\mathrm{ABH})$ is always interesting to be discussed by various circles of society. This is because the community considers that the age of children is a time when they should not be proper to do things related to law violations. The emergence of $\mathrm{ABH}$ is usually preceded by a child's behavior called delinquency. According to Kartono, delinquency is a social pathological symptom caused by a form of social neglect. As a result, an individual will develop deviant forms of behavior.[1] This deviant behavior is influenced by various motives such as wrong association, trial and error, under threat or influence from adults, efforts to defend themselves, and so on. Social and cultural influences play a large role in the formation or conditioning of individual criminal behavior.[2] The behavior of children categorized as criminalized shows signs of lack of conformity with social norms.

During their sentence, many children lose their various rights, such as the right to freedom, the right to socialize, and the right to education. In human rights instruments at the national and international levels, children are positioned as a vulnerable group of people who are 
obliged to receive special or special treatment, and the state has the responsibility to ensure the protection and fulfillment of these special children's rights.[3] In general, the conditions of prisons and prisons for children in Indonesia mean that child prisoners and prison students have not fully received a guidance program that is oriented towards fulfilling children's rights to obtain an education.[4]Regarding the assimilation process, the LPKA needs to give special consideration to $\mathrm{ABH}$ who are involved in criminal acts. They need to be specially coached within LPKA concerning the safety and psychological risks of children if they go to school outside LPKA. It was found that not all ABHs had the same opportunity to obtain an education. There are still correctional students attending education outside LPKA at their own expense. This is of course a cause for concern because it limits access to education for correctional students who come from underprivileged families.

Another problem encountered is the varying ages of $\mathrm{ABH}$ which automatically require educational services according to the child's education level. Children with special needs, for example, ABH who are illiterate or who are too "old" to attend primary school or junior high school. Therefore, we need an appropriate education and coaching model. This study describes an educational study for $\mathrm{ABH}$, namely the Community Learning Activity Center (PKBM).

\section{Method}

The approach used in this research is a qualitative approach using descriptive-analytical methods. A qualitative approach is used to describe phenomena or events that exist in a particular individual or group of society. Data collection was carried out by reviewing existing documents, both from the law and from the studies of other researchers. The researcher then analyzes and concludes the existing findings. It is expected to provide an appropriate form of education for children dealing with the law $(\mathrm{ABH})$ so that their education can be strived for.

\section{Results and Discussion}

\subsection{System of Special Development Institution for Children (LPKA)}

Indonesia is a constitutional State; therefore, it is necessary to uphold the function of law both as a form of struggle for justice and protection and fulfillment of individual rights. In the case of $\mathrm{ABH}$, the LPKA system must provide protection and training for $\mathrm{ABH}$ preparations to return them to society as good citizens. The country is responsible for guiding $\mathrm{ABH}$ to regret and to educate $\mathrm{ABH}$ to become a useful member of Indonesian society. The institutional development of prisoners is currently known as the prison system. The system has the characteristics of ten main principles which all boil down to philosophy, the prisoner is not a convict.[5] New ideas about guidance that are no longer about deterring but also an effort to rehabilitate the assisted residents, so that the correctional establishment gave birth to a development known as the Correctional System.

As for what is meant by the Correctional System in Law No.12 of 1995 Article (1) Paragraph (2) is: "The Correctional System is an arrangement regarding the direction and boundaries and methods of fostering Correctional Assistance (WBP) based on Pancasila which is implemented in an integrated manner. between the supervisor, who is fostered, and the community to improve the quality of the Correctional Assisted Citizens so that they are aware of mistakes, improve themselves, and do not repeat criminal acts so that they can be 
accepted back into the community, can actively play a role in development, and can live naturally as good citizens and to be responsible".

Correctional Institutions need to accommodate the interests of continuing interests and talents in the context of the personal development of residents. For example, to be involved in cooperation and all kinds of work activities that can provide added value to the material. For this reason, prisons must be able to develop cooperation with third parties which in the future can be projected to become industrial prisons in prisons. In their daily activities, officers must not influence the children's mentality such as frightening, threatening, or even committing acts of violence. Officers are also strictly prohibited from engaging in actions that can create hatred or a desire for revenge from children against officers.

The opportunity to always play and learn must be put forward and the level of interaction with the environment and family must be planned. Children's education must always be available to the highest level, either formal or non-formal.[4]Skills or majors are provided according to the talents and interests of the child or adapted to the progress of society, for example, directed to master technology. In general, child prisons in name and physical form must be changed and reflect child protection. Development models must be specially designed following the specificities of crimes that are of international concern. The special treatment program includes treatment of $\mathrm{ABH}$ who is involved in narcotics cases, sexual crimes, and serious crimes, namely murder. As much as possible, the treatment should be in the form of rehabilitation by creating a collaborative program with the Ministry of Health and the Ministry of Social Affairs.

\subsection{Child Prison Problems in Indonesia}

Guidance programs and activities carried out in prisons are directed at developing independent human beings. However, in reality, the implementation of laws related to the functions of a correctional institution is only limited to ideal expectations. Various facts show that what happens in all correctional institutions in Indonesia is the lack of management of correctional institutions in Indonesia. Various problems that arise continue without ever finding the right solution even though at the same time it has always been criticized by various elements of society. Several problems in fulfilling the rights to children's education in child prisons that need attention, namely:

a. Lack of information for families of children who are faced with the law.

b. Policies that have not been oriented towards fulfilling children's rights in conflict with the law.

c. The low level of coordination in the fulfillment of children's rights to education in prisons.

d. Planning that is not accompanied by careful budgeting.

e. Lack of educational facilities and infrastructure in prisons.

\subsection{Legal Guarantee for Children's Education}

Specifically, the basic rights of children are described in Article 4 of Law no. 23 of 2002 concerning Child Protection includes the right to life, protection, development, and participation. The views and thoughts on the fulfillment and protection of children's rights demand that adults (biological parents, government, society) are fully responsible for every child born by anyone, anywhere.[6] Protection for ABH is carried out by seeking detention as a last resort. If the legal process continues, protection for them can be carried out based on the 
community, or in legal terms, it is called diversion and restorative justice (RJ). The goal is to restore the relationship between the victim and the perpetrator based on prevailing values by agreeing to open communication between $\mathrm{ABH}$ and the victim and their respective families involving experts, communities, community leaders, and traditional leaders, and the handling of the child's case must be a part of the child prevention program to become ABH.[7] It is hoped that the regulations and policies for the protection of $\mathrm{ABH}$ by integrating the perspectives of children can minimize the practice of violating the rights of $\mathrm{ABH}$, especially in the field of education. In the case of $\mathrm{ABH}$, education is one of the basic rights that are vulnerable to being neglected, especially since the number of $\mathrm{ABH}$ is increasing from year to year.

The 1945 Constitution of the Republic of Indonesia Article 31 paragraph (1) states that "every citizen has the right to education", and paragraph (3) emphasizes that "the government undertakes and implements a national education system that enhances faith and piety as well as noble morals. to educate the nation's life ". Likewise, Law Number 20 of 2003 concerning the National Education System, Article 5 states that "every citizen has the same right to obtain quality education and is entitled to the opportunity to improve lifelong education, even citizens with physical, emotional, and physical disabilities. mental, intellectual, social and citizens in remote or underdeveloped areas as well as remote indigenous peoples have the right to receive special education or service education, including citizens who have the potential for special intelligence and talents". In the context of fulfilling the right to education and teaching for correctional students (andikpas), in this case, a criminal child, Law Number 12 of 1995 concerning Corrections Article 22 paragraph (1) states that "criminal children obtain the rights referred to in Article 14, except letter g".

The rights of students in correctional institutions as regulated in Article 14 of Law Number 12 of 1995 contain the right to get education and teaching. Furthermore, Law Number 39 of 1999 concerning Human Rights also emphasizes Article 60, that "every child has the right to receive education and teaching in the framework of personal development according to his interests, talents fand level of intelligence". Children are a gift from God as part of the younger generation who are assets and at the same time the successor of the nation. Children are also a human resource that has a strategic meaning and role in national development. Such is the importance and strategic importance of the existence of children in the dynamics of social, national, and state life based on Pancasila and the 1945 Constitution of the Republic of Indonesia.

\subsection{Community-Based Education}

The term community-based education was originally introduced by Comton and McClusky by using the term "community education for development" which is defined as a process in which every member of the community is present to raise every problem and need, find solutions among them, mobilize available resources, and carry out an activity plan or learning or both.[8] The concept of Community Based Education (PBM) is from the community, by the community, and for the community. From this concept, it can be stated that PBM is education that is managed by the community by utilizing existing facilities in the community and emphasizes the importance of community participation in every learning activity, and aims to answer community needs. The PBM concept and practice are to create a smart, skilled, independent, and competitive society by carrying out learning programs following the needs of the community. The process of developing a Community Based Education Program (PBM) should follow several field procedures:[8] 


\section{a) Identify Needs}

The process of identifying problems faced and the needs of the target group or community. At this stage, an assessment of resource support is carried out and the obstacles that may be faced. Observation and dialogue methods need to be used to identify the real needs of the target group.

\section{b) Planning}

Systematic program planning is very important for the achievement of the overall objectives of the PBM program. Each PBM program consists of goals/objectives, implementation mechanisms, components and processes, required resources, institutions that need to be involved taking into account their sustainability. This planning activity also includes organizational development which will later be responsible for implementing the PBM program.

\section{c) Implementation of Programs in the Field or the Community}

As a comprehensive program implementation system, the targets to be achieved must be formulated realistically and flexibly. All required resources must be described. The institutions and individuals involved must also be listed. The sustainability of the program in terms of perspective should also be described.

\section{d) The Process of Supervising and Monitoring the Implementation of the PBM Program}

Internal mechanisms for the study, supervision, and monitoring system must be established so that the general public can also supervise and monitor the implementation of the PBM program.

\section{e) Program Evaluation and Development}

The principle to be used in PBM is the effective use of any available resources and educated personnel to evaluate and develop PBM programs. The implementation of teaching and learning activities is a place for various learning activities needed by the community according to their interests and needs with the PBM approach. The programs that are carried out can vary but must be following the conditions, potentials, and needs of the community to be relevant, and the programs must be meaningful and useful. These programs include Equality Education: Package A, Package B, and Package C, Vocational Education, Life Skills, and Courses. Mental and Spiritual or Religious Education is also needed.

\subsection{Application of Community Based Education for ABH}

From a human rights perspective, the ideal implementation of children's education is nondiscriminatory. This means that it cannot be distinguished even if a child has the status of a correctional student. Children still have the right to attend education. However, there are special conditions faced by ABH if they have to take part in Teaching and Learning Activities (KBM) outside the Special Development Institution for Children (LPKA), namely safety considerations for children who are involved in criminal acts of drug abuse which can affect 
the social conditions of the community. ABH education and guidance programs in LPKA need to involve/participate in various parties (sectors) as a support for the success of the concept of correctional. The success of an LPKA must involve the participation of various parties such as:

Collaboration with the local Dinas is also needed, for example for skills training and business capital. LPKA needs to collaborate with the labor office and the social service to assist with the facilities (sewing machines, screen printing tools, workshop tools, salon equipment, and so on). Meanwhile, the UKM and cooperative offices are intended to provide capital funds so that when ABH leaves LPKA, they already have the knowledge, skills and are ready to enter the community independently. In realizing the education and training program for ABH in LPKA, a strong commitment and substantial budget support are needed, because it requires a change in the mindset of officers, changes in the form of child-friendly prisons, good facilities, and infrastructure, availability of adequate experts (classification of qualified teachers).

The curriculum offered does not have to be the same as the applicable educational curriculum in public schools, because the abilities and needs of correctional students can be different from those of children in general. Therefore, it is necessary to assess each child to find out their abilities and needs. The implementation of education and coaching programs for $\mathrm{ABH}$ can run well when management and leadership are also going well. The Head of the Corrections Division and the Head of the LPKA are expected to be able to manage the institution by involving various external parties, including local governments, NGOs, the private sector, and the community. This can be realized if there is a common perception of all Heads of Corrections and Heads of LPKA.[9]

\section{Conclusion}

Even though a child is undergoing punishment or counseling in a juvenile prison, the provisions regarding children's rights must still apply to the child. Their existence in juvenile prisons and their status as criminal children does not eliminate their inherent rights and must be fulfilled and well protected. In realizing the PKBM referred to, participation from various institutions is very influential in its success. The concept of Community-Based Education as a form of fulfillment of $\mathrm{ABH}$ education shows that the principles of human rights (participation and non-discrimination) can be accepted and applied to LPKA. Henceforth, the model of education and fostering children must be able to provide a minimum standard of education in LPKA, both curriculum standards that are following the capacity of the correctional students as well as the facilities and infrastructure that must be available. Meanwhile, in terms of the availability of teaching staff, expertise in the field of education is required as the main requirement for civil service registration at LPKA.

\section{Reference}

[1] K. Kartini, Social Pathology. Jakarta: PT. Raja Grafindo, 2005.

[2] Nunung Unayah and M. Sabarisman, "The phenomenon of juvenile delinquency and crime," Socio Inf., vol. 1, no. 2, 2016.

[3] OC Nugroho, "The Role of Correctional Facilities in the Juvenile Criminal Justice System Reviewed from a Human Rights Perspective," J. HAM, pp. 161-174, 2017. 
[4] Oki Wahju Budijanto, "Fulfilling the Right to Education for Correctional Students in Special Development Institutions for Children," J. Ilm. Wisdom. Huk., vol. 7, no. 1, 2013.

[5] I. Petrus, Pandjaitan, and P. Simorangkir, Correctional Institutions in the Perspective of the Criminal Justice System. Jakarta: Pustaka Sinar Harapan, 1995.

[6] Hadi Supeno, Criminalization of Children Offers Radical Ideas of Juvenile Justice Without Criminalization. Jakarta: PT Gramedia Pusaka Utama., 2010.

[7] Marlina, Juvenile Criminal Justice in Indonesia, Development of the Concept of Diversion and Restorative Justice. Medan: Refika Aditama., 2012.

[8] Zubaedi, Community Based Education. Yogyakarta: Student Library, 2006.

[9] Nistiarisa Angelina, "Fulfilling the Need for Formal Education Rights for Children Facing the Law as an Effort to Create a Child-Friendly City in Surakarta," Univ. Sebel. March 2013. 